\title{
Persistent organic pollutants (POPs) in fish from two coastal lagoons of the central Mexican Pacific
}

\author{
Eduardo Ramírez-Ayala $^{1,2} \mathbb{B}^{\mathbb{D}}$, Miguel A. Arguello-Pérez ${ }^{1}(\mathbb{D})$, Adrián Tintos-Gómez ${ }^{1,2}$ \\ Jesús H. Hernández-Anguiano ${ }^{3}{ }^{\mathbb{D}}$, Rebeca Y. Pérez-Rodríguez ${ }^{4}{ }^{\mathbb{B}}$, César A. Ilizaliturri-Hernández ${ }^{5}$ \\ Gabriel Núñez-Nogueira ${ }^{6}$ \& César A. Sepúlveda-Quiroz ${ }^{7}$ \\ ${ }^{1}$ Doctorate Program in Sciences in Biosystematics, Ecology and Management of Natural and Agricultural \\ Resources (BEMARENA), Department of Studies for the Development of the Coastal Zone University of \\ Guadalajara, Jalisco, Mexico \\ ${ }^{2}$ Renewable Energy Research Center, Technical Secretariat of the Academic Area \\ Technological University of Manzanillo, Colima, Mexico \\ ${ }^{3}$ Department of Geomatics and Hydraulics Engineering Division of Engineering \\ University of Guanajuato, Guanajuato, Mexico \\ ${ }^{4}$ DCNyE Spectroscopy, Chromatography and Calorimetry Services Laboratory, Department of Chemistry \\ Division of Natural and Exact Sciences, University of Guanajuato, Guanajuato, Mexico \\ ${ }^{5}$ Center for Applied Research in Environment and Health (CAREH), CIACyT-School of Medicine \\ Autonomous University of San Luis Potosi, Mexico \\ ${ }^{6}$ Hydrobiology and Aquatic Pollution Laboratory, Academic Division of Biological Sciences (DACBiol) \\ Juárez Autonomous University of Tabasco, Villahermosa, Tabasco, Mexico \\ ${ }^{7}$ Laboratory of Tropical Aquaculture, Academic Division of Biological Sciences (DACBiol) \\ Juárez Autonomous University of Tabasco, Villahermosa, Tabasco, México \\ Corresponding author: Adrián Tintos-Gómez (adrian.tintos@academicos.udg.mx)
}

\begin{abstract}
Mexico has a great variety of aquatic ecosystems; however, most of them present significant contamination levels. Despite the efforts to monitor toxic and bioaccumulative persistent pollutants, they are still insufficient and outdated data from Mexican coasts, especially in polychlorinated biphenyls (PCBs) and polyaromatic hydrocarbons (PAHs), due to the number of aquatic bodies that have received little or no attention. In this regard, the Mexican Pacific's coastal zones and their aquatic ecosystems monitoring PCBs and PAHs in biota is critical because it allows us to estimate the potential risk to human health. This work aimed to determine the total concentration of polychlorinated biphenyls $\left(\sum \mathrm{PCBs}\right)$ and total polyaromatic hydrocarbons $\left(\sum \mathrm{PAHs}\right)$ in the muscle of fish collected in two coastal lagoons of the central Mexican Pacific and to determine the noncarcinogenic risk ratio (HQ) based on the monthly per capita consumption of national fish and the consumption of fish associated with fishing communities in Mexico. It was found that the potential risk for fishing communities is considerably higher and correlates to the rate of fish consumption, highlighting their vulnerability to these contaminants.
\end{abstract}

Keywords: persistent organic pollutants; non-carcinogenic hazard quotient; coastal lagoons; fish intake; fishing communities

The presence of persistent organic pollutants (POPs) in aquatic ecosystems is a topic of global interest and concern for researchers and government agencies and, more recently, for the general public. POPs have a significantly longer life, promoting their persistence in sediments, water, and organisms. Some of the most important POPs are chlorinated and brominated aroma- tics; polychlorinated biphenyls (PCBs), polychlorinated dibenzo-p-dioxins, and-furans ( $\mathrm{PCDD} / \mathrm{Fs}$ ), polybrominated diphenyl ethers (PBDEs), and different organochlorine pesticides (OCPs, e.g. DDT), as well as certain polyaromatic hydrocarbons (PAHs) (Jones \& de Voogt 1999, Behera et al. 2018). Due to their persistence, bioaccumulation, toxicity, and biomagnification, 
POPs have a negative impact on both human and ecosystem health (Xu et al. 2013) when introduced to aquatic ecosystems, and POPs are mainly associated with sediments that will act as their main reservoir. POPs will be stable for long periods due to their low solubility in water and high affinity to organic matter (Brázová et al. 2015).

In the same way, these substances can be persistent in the water column, thus remaining available to aquatic organisms (Ribeiro et al. 2016), which can come into contact with them through breathing, ingestion, or body surfaces (Baali \& Yahyaoui 2019); thus, passing to the trophic chains. Once there, POPs will reach primary consumers and top predators subsequently (RomeroRomero et al. 2017). Therefore, POPs might represent a serious risk of compromising food safety (Guo et al. 2019).

However, research has focused on monitoring pesticide residues, paying little attention to other relevant contaminants such as PCBs and PAHs, which are associated with a wide variety of adverse effects, either in wild species and human exposures (AbdelShafy \& Mansour 2016, Faroon \& Ruiz 2016, Baali \& Yahyaoui 2019). Like the rest of the POPs, PCBs and PAHs are persistent, toxic, and bioaccumulative compounds, widely distributed in the world's aquatic ecosystems (Abdel-Shafy \& Mansour 2016, Islam et al. 2018).

Since the 1940s, PCBs have been widely used in electrical transformers and capacitors, fluorescent lamp ballasts, fluids for temperature exchange, printing inks, hydraulic fluids, marine paints, and carbon paper (González-Jáuregui et al. 2014). The major source of PAH emission is the incomplete combustion of fossil fuels (García-Ruelas et al. 2004). On the aquatic ecosystems of Mexico and especially concerning the fish of the central Pacific coasts, there is little information on the concentration of PCBs and PAHs. With few scientific publications on the subject, it is difficult to know the contamination levels and potential risks of these contaminants (Ramírez-Ayala et al. 2020). Like many countries, no federal programs focus on monitoring the concentration of POPs in wild aquatic organisms in Mexico. Many species are part of the main food source of many fishing communities, both in coastal and inland areas throughout the Mexican territory (CONAPESCA 2017). However, there is no official information that allows human consumers to know the risks involved in consuming aquatic resources polluted with POPs and establishing safe consumption and risk areas. Researchers have been conducting studies for the last 20 years on different organisms, including fish and crustaceans (Ramírez-Ayala et al. 2020). For example, clams (Chione californiensis) from three coastal lagoons (Yavaros, Altata, and Reforma lagoons) in the eastern coast of the Gulf of California present organochlorine pesticides a tissue residue, which reflects environmental pollution into coastal lagoons (Vargas-González et al. 2016). Furthermore, another study showed the levels of POPs in muscle tissue of five fish species from Coatzacoalcos River (Veracruz-Mexico), providing an idea of the health status of that particular ecosystem (GonzálezMille et al. 2010). This study aimed to determine the concentration of PCBs and PAHs in the muscle of fish collected in two coastal lagoons of the central Mexican Pacific (where there are no previous reports in this regard) and evaluate the potential health risk to local human consumers.

The Barra de Navidad Lagoon is located in the coastal zone of the state of Jalisco in the municipality of Cihuatlán $\left(19^{\circ} 11^{\prime} \mathrm{N}, 104^{\circ} 39^{\prime} \mathrm{W}\right)$, a municipality with about 40,000 inhabitants and whose economic activity is mainly oriented to tourism, agriculture, and riverine fishing (INEGI 2017a). This lagoon has a water surface of 334 ha and freshwater inlets from two river sources, the Arroyo Seco River and the Marabasco River, and water exchanges with the sea through a mouth of 100 m wide (Aguilar-Betancourt et al. 2016).

The Cuyutlán Lagoon with an area of 38,884 ha is located in the municipality of Manzanillo in the state of Colima $\left(19^{\circ} 03^{\prime} \mathrm{N}, 104^{\circ} 19^{\prime} \mathrm{W}\right)$, which has about 184,000 inhabitants, and whose economy is mainly oriented to industry (port, electricity, mining), tourism and riverine fishing (INEGI 2017b). The lagoon has a distinctive geographical feature, divided into four bodies of water, called "vasos" (I, II, III and, IV) delimited by natural physical barriers and artificial systems regulating the water exchange and sediments dragging among vasos (Torres \& Quintanilla-Montoya 2014). The Cuyutlán Lagoon receives limited fresh-water contributions from the Coahuayana River and the Armería River.

For this research, fish sampling was carried out in the Barra de Navidad Lagoon (Jalisco) and the Cuyutlán Lagoon (Colima). Sampling was carried out in March 2018 by local fishermen for three days (one per week). The organisms were collected in the fishing areas most frequently used by local fishermen, and the catches were made by traditional fishing gear (cast net and trammel). Once the specimens were collected, they were put on ice and transported to the laboratory where biometric data (weight and height) were taken, packed individually in airtight plastic bags, and kept frozen at $-20^{\circ} \mathrm{C}$ until further analysis.

Muscle samples $(10 \mathrm{~g})$ were homogenized in a food processor; subsequently, the macerate was dried with excess anhydrous $\mathrm{Na}_{2} \mathrm{SO}_{4}$ (in a proportion of $3: 1$, $\mathrm{Na}_{2} \mathrm{SO}_{4}$ : tissue) before extraction with solvents. Fish 
tissue macerated was mixed with $200 \mathrm{~mL}$ of dichloromethane-methanol solvent mixture (2:3; v:v), and extraction was carried out through a Soxhlet extraction apparatus for six hours. The extractions were carried out three times. Next, the samples' cleanup and concentration were carried out on C18SPE columns in $5 \mathrm{~mL}$ fractions. The C18 SPE column was equilibrated with type 1 (ultrapure) water. After passing the entire sample through the column, it was eluted with $20 \mathrm{~mL}$ of a solvent mixture of $n$-hexane/dichloromethane (1:1 $\mathrm{v} / \mathrm{v})$ and dried with a rotary evaporator under a highpressure vacuum and then redissolved in $1 \mathrm{~mL}$ of methanol for analysis by gas chromatography, accordingly to USEPA standard methods (SW-846 compendium methods; USEPA 2015). For the quantification of PCBs, a Supelco SLB-5ms, L $\times$ ID capillary column was used $(30 \mathrm{~m} \times 0.25 \mathrm{~mm})$, capillary thickness (df: $0.25 \mu \mathrm{m}$ ), while for PAHs, a Supelco PTE-5 L $\times$ ID capillary column was used $(30 \mathrm{~m} \times 0.25 \mathrm{~mm})$, capillary thickness (df $0.25 \mu \mathrm{m}$ ). The GC was coupled to a single mass spectrometer (MS) single quadrupole in SIMS mode with negative ion chemical ionization (NICI) operating conditions (GC, Hewlett-Packard G1800C, USA). The standards used for all compounds were 200 $\mu \mathrm{g} \mathrm{mL}{ }^{-1}$ Merck Sigma-Aldrich certified reference material dissolved in dichloromethane. The measurement conditions adjusted for this analysis were: equipment detection limit: $0.02-0.2 \mathrm{ng} \mathrm{g}^{-1}$; limit of quantification of the method: $0.5-2 \mathrm{ng} \mathrm{g}^{-1}$; recovery rate (\% Rec): $[91 \%, 95 \%] \pm 1.5 \%$; matrix effect (\% ME): [$9 \%,-3 \%] \pm 0.5 \%$; and the curve fit $\left(\mathrm{R}^{2}\right):[0.992,0.998]$. Internal standards for each compound of interest were used with $10 \mathrm{ng} \mathrm{mL}^{-1}$ for the $\% \mathrm{Rec}$ and $-\% \mathrm{ME}$ determinations.

The potential health risk due to PCB ingestion and PAHs associated with fish consumption was evaluated, considering the $\mathrm{HQ}$ as an indicator. The equation $\mathrm{HQ}=$ E / RfD was used (Newman \& Unger 2002), where E is the level of exposure or consumption of the pollutant and was calculated by the equation $\mathrm{E}=\mathrm{C} \times \mathrm{I} / \mathrm{W}$, where $\mathrm{C}$ is the concentration of the pollutant $\left(\mu \mathrm{g} \mathrm{g}^{-1} \mathrm{Ww}\right), \mathrm{I}$ is the per capita ingestion rate $\left(\mathrm{g} \mathrm{d}^{-1}\right)$, and $\mathrm{W}$ is the average weight $(\mathrm{kg})$. The ingestion rate (I) was $35 \mathrm{~g} \mathrm{~d}^{-1}$ as a national per capita average (CONAPESCA 2017) and $300 \mathrm{~g} \mathrm{~d}^{-1}$ for fishing communities in Mexico (ZamoraArellano et al. 2017, Astorga-Rodríguez et al. 2018) and a $\mathrm{W}$ of $70 \mathrm{~kg}$ as the weight of an average adult (Walpole et al. 2012). RfD is the reference dose $\left(\mu \mathrm{g} \mathrm{kg}^{-1}\right.$ $\mathrm{kg}^{-1}$ of weight d $\mathrm{d}^{-1}$ ), and an RfD of $0.02 \mathrm{ng} \mathrm{g}^{-1} \mathrm{ww}$ was considered for $\sum$ PCBs (USEPA 2000) and of $40 \mathrm{ng} \mathrm{g}^{-1}$ ww for $\sum$ PAHs (TPHCWG 1999). The differences in PBCs and PAHs concentration were evaluated with a Kruskal-Wallis-H test at a statistical significance level of $P<0.05$ with specialized software (IBM-SPSSStatistics, Ver.21).

Fourteen specimens were analyzed from the present study, and most were identified down to the species level. Macroscopic inspection after dissection revealed that most of the organisms analyzed were immature individuals, except for Mugil sp. and Ariopsis guatemalensi; this may be since the coastal lagoons act as a hatchery for large predators (Aguilar-Betancourt et al. 2016). Table 1 shows $\sum$ PAHs and $\sum$ PCBs' values found in muscle samples of the 14 species of fish collected in both lagoons.

Regarding $\sum$ PAHs' concentration, the maximum concentrations were found in Polydactylus approximans (7.85 ng g ${ }^{-1}$ ww) and Acanthurus xanthopterus (16.63 ng $\mathrm{g}^{-1}$ ww) for the Cuyutlan Lagoon and the Barra de Navidad Lagoon, respectively. Simultaneously, in $\sum$ PCBs, they were detected in Lutjanus sp. $\left(0.40 \mathrm{ng} \mathrm{g}^{-1}\right.$ $\mathrm{ww})$ and Ariopsis guatemalensis $\left(0.44 \mathrm{ng} \mathrm{g}^{-1} \mathrm{ww}\right)$ for the Cuyutlán Lagoon and the Barra de Navidad Lagoon, respectively. In this study, no differences were found in $\sum$ PAHs and $\sum$ PCBs between the trophic level. The HQs associated with fish consumption from the area analyzed is shown (Table 2).

The HQ calculation shows that the risk associated with fish consumption contaminated by PCBs and PAHs in the study area can be considered low based on the national fish consumption rate (HQ1). However, if the rate of consumption of fishing communities (HQ2) is considered, the value of HQ increases considerably ( $\mathrm{HQ}>2$ ).

The most studied effects related to exposure to POPs, PCBs, and PAHs are genotoxic and carcinogenic (mainly of certain congeners such as benzo (a) pyrene, naphthalene, chrysene, benzo (a) anthracene, benzo (k) fluoranthene, and benzo (b) fluoranthene in the case of PAHs, or dioxin-type or coplanar PCBs) (Gou et al. 2019, Honda \& Suzuki 2020).

On the other hand, several other adverse effects have been related to chronic exposure to these pollutants, such as reproductive health, growth, embryonic development, and behavior, both in animals and humans (Gou et al. 2019). Although the potential effect of both PAHs and PCBs depends mainly on the specific compound involved, the environmental sources of exposure are complex mixtures, making it difficult to elucidate the long-term effects. In this sense, the monitoring of different environmental matrices (mainly biota) is vital in conserving the health of aquatic ecosystems (Ramírez-Ayala et al. 2020).

According to the above, monitoring the levels of pollutants in fishing resources is an excellent tool to identify and define environmental health. As previously 
Table 1. Concentration range (minimum and maximum) of total polychlorinated biphenyls ( $\sum$ PCBs) and total polyaromatic hydrocarbons $\left(\sum \mathrm{PAHs}\right)\left(\mathrm{ng} \mathrm{g}^{-1}\right.$, wet weight $)$ in fish muscle. Sample size $(\mathrm{n}=8)$. $\sum$ PCBs: total polychlorinated biphenyls, $\sum$ PAHs: total polyaromatic hydrocarbons, DL: detection limit. Trophic level based on food items: values from FishBase 2021. No significant differences were found: $P<0.05$.

\begin{tabular}{|c|c|c|c|c|c|}
\hline Site & Species (trophic level) & $\begin{array}{l}\text { Common name } \\
\text { (local) }\end{array}$ & $\begin{array}{l}\text { Size } \\
(\mathrm{cm})\end{array}$ & $\sum \mathrm{PCBs}$ & $\sum$ PAHs \\
\hline \multirow[t]{7}{*}{ Cuyutlán } & Mugil sp. $(2.0$ - 3.2) & Lisa & $25 \pm 3$ & $<\mathrm{DL}-0.06$ & $0.60-7.45$ \\
\hline & Ariopsis guatemalensis $(3.6 \pm 0.5)$ & Bagre & $20 \pm 4$ & $<$ DL-0.19 & $4.56-6.80$ \\
\hline & Polydactylus approximans $(3.6 \pm 0.6)$ & Bonito & $16 \pm 1$ & $<$ DL-0.20 & $0.57-7.85$ \\
\hline & Centropomus sp. $(3.6-4.2)$ & Constantino & $25 \pm 5$ & $<$ DL-0.04 & $1.10-1.91$ \\
\hline & Caranx caninus $(3.9 \pm 0.61)$ & Jurel & $15 \pm 2$ & $<$ DL-0.23 & $0.95-2.45$ \\
\hline & Lutjanus sp. $(3.1-4.2)$ & Pargo & $16 \pm 2$ & $<$ DL-0.40 & $1.23-5.70$ \\
\hline & Elops affinis $(4.1 \pm 0.70)$ & Machete & $25 \pm 2$ & $<$ DL-0.26 & $1.50-7.19$ \\
\hline \multirow[t]{11}{*}{ Barra de Navidad } & Chanos chanos $(2.4 \pm 0.20)$ & Sábalo & $30 \pm 1$ & $<$ DL-0.08 & $0.66-8.66$ \\
\hline & Mugil sp. $(2.0$ - 3.2) & Lisa & $33 \pm 9$ & $<$ DL-0.13 & $1.20-7.23$ \\
\hline & Acanthurus xanthopterus $(2.9 \pm 0.36)$ & Navajero & $30 \pm 4$ & $<$ DL-0.12 & $0.96-16.63$ \\
\hline & Diapterus peruvianus $(3.7 \pm 0.2)$ & Mojarra & $17 \pm 5$ & $<$ DL-0.07 & $1.00-4.37$ \\
\hline & Ariopsis guatemalensis $(3.6 \pm 0.5)$ & Bagre & $34 \pm 6$ & $<$ DL-0.44 & $0.36-9.62$ \\
\hline & Haemulopsis sp. (3.2 - 3.6) & Ronco & $23 \pm 8$ & $<$ DL-0.16 & $0.36-9.46$ \\
\hline & Selene sp. $(3.3-4.3)$ & Tostón & $25 \pm 3$ & $<\mathrm{DL}$ & $3.48-5.08$ \\
\hline & Achirus mazatlanus $(3.2 \pm 0.45)$ & Lenguado & $15 \pm 2$ & $<$ DL-0.08 & $0.40-8.67$ \\
\hline & Caranx caninus $(3.9 \pm 0.61)$ & Jurel & $18 \pm 1$ & $<$ DL-0.09 & $0.68-3.21$ \\
\hline & Peprilus snyderi $(4.1 \pm 0.2)$ & Gavilán & $16 \pm 1$ & $<$ DL-0.16 & $0.73-4.55$ \\
\hline & Lutjanus sp. $(3.1-4.2)$ & Pargo & $21 \pm 3$ & $<$ DL-0.05 & $0.53-7.23$ \\
\hline
\end{tabular}

Table 2. Non-carcinogenic risk ratio (HQ) associated with the consumption of fish from the Cuyutlán Lagoon (Colima) and Barra de Navidad Lagoon (Jalisco), Mexico. HQ1: calculated based on the national average fish intake of $35 \mathrm{~g} \mathrm{~d}^{-1}$. HQ2 was calculated based on fish consumption reported in some fishing communities in Mexico of 200 to $4000 \mathrm{~g} \mathrm{~d}^{-1}$. $\sum$ PCBs: total polychlorinated biphenyls; $\sum$ PAHs: total polyaromatic hydrocarbons. Trophic level: values from FishBase 2021.

\begin{tabular}{|c|c|c|c|c|c|}
\hline \multirow{2}{*}{ Site } & \multirow{2}{*}{ Species (trophic level) } & \multicolumn{2}{|c|}{$\sum \mathrm{PCBs}$} & \multicolumn{2}{|c|}{$\sum$ PAHs } \\
\hline & & $\mathrm{HQ}_{1}$ & $\mathrm{HQ}_{2}$ & $\mathrm{HQ}_{1}$ & $\mathrm{HQ}_{2}$ \\
\hline \multirow[t]{7}{*}{ Cuyutlán } & Mugil sp. $(2.0-3.2)$ & 0.30 & 2.57 & $<0.1$ & 0.16 \\
\hline & Ariopsis guatemalensis $(3.6 \pm 0.5)$ & 0.95 & 8.14 & $<0.1$ & 0.15 \\
\hline & Polydactylus approximans $(3.6 \pm 0.6)$ & 1.00 & 8.57 & $<0.1$ & 0.17 \\
\hline & Centropomus sp. (3.6 - 4.2) & 0.20 & 1.71 & $<0.1$ & 0.04 \\
\hline & Caranx caninus $(3.9 \pm 0.61)$ & 1.15 & 9.86 & $<0.1$ & 0.05 \\
\hline & Lutjanus sp. $(3.1-4.2)$ & 2.00 & 17.14 & $<0.1$ & 0.12 \\
\hline & Elops affinis $(4.1 \pm 0.70)$ & 1.30 & 11.14 & $<0.1$ & 0.15 \\
\hline \multirow[t]{10}{*}{ Barra de Navidad } & Chanos chanos $(2.4 \pm 0.20)$ & 0.40 & 3.43 & $<0.1$ & 0.19 \\
\hline & Mugil sp. $(2.0-3.2)$ & 0.65 & 5.57 & $<0.1$ & 0.15 \\
\hline & Acanthurus xanthopterus $(2.9 \pm 0.36)$ & 0.60 & 5.14 & $<0.1$ & 0.36 \\
\hline & Diapterus peruvianus $(3.7 \pm 0.2)$ & 0.35 & 3.00 & $<0.1$ & 0.09 \\
\hline & Ariopsis guatemalensis $(3.6 \pm 0.5)$ & 2.20 & 18.86 & $<0.1$ & 0.21 \\
\hline & Haemulopsis sp. (3.2 - 3.6) & 0.80 & 6.86 & $<0.1$ & 0.20 \\
\hline & Achirus mazatlanus $(3.2 \pm 0.45)$ & 0.40 & 3.43 & $<0.1$ & 0.11 \\
\hline & Caranx caninus $(3.9 \pm 0.61)$ & 0.45 & 3.86 & $<0.1$ & 0.19 \\
\hline & Peprilus snyderi $(4.1 \pm 0.2)$ & 0.80 & 6.86 & $<0.1$ & 0.07 \\
\hline & Lutjanus sp. $(3.1-4.2)$ & 0.25 & 2.14 & $<0.1$ & 0.10 \\
\hline
\end{tabular}

mentioned, a few studies about the concentration of PCBs and PAHs in environmental matrices of aquatic ecosystems, especially in biota, in Mexico. For exam- ple, Carvalho et al. (2009) reported PCB values in Lepisosteus tropicus muscle of $0.782 \mathrm{ng} \mathrm{g}^{-1}$ dry weight and values of 0.013-4.847 $\mathrm{ng} \mathrm{g}^{-1}$ dry weight in the soft 
tissue of Crassostrea spp., collected in the Laguna de Términos, Campeche. Similarly, Espinosa-Reyes et al. (2012) reported mean concentrations of PCBs in the muscle of Centropomus parallelus $\left(0.20 \mathrm{ng} \mathrm{g}^{-1}\right)$, Mugil cephalus (0.10 $\left.\mathrm{ng} \mathrm{g}^{-1}\right)$, Eugerres axillaris $\left(0.10 \mathrm{ng} \mathrm{g}^{-1}\right)$, Ariopsis felis $\left(0.30 \mathrm{ng} \mathrm{g}^{-1}\right)$, and Callinectes sp. $(0.30 \mathrm{ng}$ $\mathrm{g}^{-1}$ ), wet weight, respectively, collected from the Coatzacoalcos River estuary, Veracruz, Mexico. On the other hand, Jaward et al. (2012) discovered PAHs values in Penaeus vannamei muscle of $36-498 \mathrm{ng} \mathrm{g}^{-1}$ of wet weight collected in the Urias Estuary, Sinaloa, Mexico. Other studies around the world have reported similar values to those detected here. For example, Tongo et al. (2018) referred to PAHs of $65 \mathrm{ng} \mathrm{g}^{-1}$ wet weight concentrations in $M$. cephalus muscle collected in the Bonny River, Nigeria delta. In the same way, Nozar et al. (2013) found values of PAHs in the muscle of Lutjanus johnii and Liza subviridis of $17 \mathrm{ng} \mathrm{g}^{-1}$ wet weight for both species, collected on the Persian Gulf coast in Iran. Likewise, Mohamad et al. (2015) reported in Lutjanus argentimaculatus values of PCBs of 0.43$0.67 \mathrm{ng} \mathrm{g}^{-1}$ wet weight in the muscle on the coast of Malacca, Malaysia. On the other hand, Rose et al. (2012) indicate PAH concentrations in Lutjanus agennes muscle of $105.8 \mathrm{ng} \mathrm{g}^{-1}$ wet weight and 131.2 $\mathrm{ng} \mathrm{g}^{-1}$ wet weight in M. cephalus muscle, both collected in Okobaba, Nigeria. Batang et al. (2016) found in the Red Sea coast (Saudi Arabia), PCBs values in the muscle of $C$. chanos and $M$. cephalus of $0.22-44.3$ and 33.9-82.5 $\mathrm{ng} \mathrm{g}^{-1}$ wet weight, respectively. Likewise, Karouna-Renier et al. (2011) reported PCB concentrations in M. cephalus muscle collected in 15 sites on the coast of Florida, United States, of 3.4-59.3 $\mathrm{ng} \mathrm{g}^{-1}$ wet weight.

Under this context, it is observed that the lagoons analyzed here present relatively low $\sum$ PCBs and $\sum$ PAHs values in fish muscle. However, there are no previous reports of the concentration of PCBs and PAHs in biota; there are only reports of the concentration of PAHs in sediment for both lagoons. Garcia-Ruelas et al. (2004) found values of 1.3-2.9 $\mu \mathrm{g}$ $\mathrm{g}^{-1}$ on sediments for the Barra de Navidad Lagoon and 3.2-42.9 $\mu \mathrm{g} \mathrm{g}^{-1}$ for the Cuyutlán Lagoon. These differences could be explained by the proximity between Cuyutlán Lagoon to the thermoelectric plant and the city of Manzanillo. However, there is no significant difference regarding the concentration of PAHs and PCBs in fish muscle in both lagoons, suggesting more complex bioaccumulation processes and pollutant sources in these ecosystems. However, these PAH concentrations reported in 2004 for sediments from both lagoons have already been shown to cause various damages in fish, such as liver injuries and neoplasms observed from $1000 \mathrm{ng} \mathrm{g}^{-1}$. At lower concentrations as $50 \mathrm{ng} \mathrm{g}^{-1}$, impairments in embryonic development, inhibition of gonadal development, infertility, as well as DNA damage have already been observed (Collier et al. 2013).

The non-carcinogenic risk ratio (HQ) is the ratio of potential exposure to a substance to the level at which no adverse effects are expected. An HQ less than or equal to 1 indicates that adverse effects are unlikely to occur. Therefore, it can be considered to have a statistically significant probability that there is no associated risk. However, HQs greater than 1 are not statistical probabilities that harm will occur, but a simple quantitative statement of whether an exposure concentration exceeds the concentration of reference (RfD), with the potential risks that this entails. Based on the data presented in Table 2, it can be considered that the study area shows a relatively low-risk potential regarding the concentration of PAHs found in fish muscle, presenting an $\mathrm{HQ}<1$, both for the national consumption average and high consumption rates associated with local fishing communities. However, in the case of PCBs, the potential risk associated with fishing communities is especially high. It is recognized that the consumption of fish from sites contaminated with PCBs is one of the major sources of exposure to these contaminants (Voorspoels et al. 2004, KljakovićGašpić et al. 2015) and that it may be especially relevant in its concentration in breast milk (Fitzgerald et al. 1998) which should be evaluated in future studies.

As already mentioned, exposure to PCBs is related to various health disorders. For example, it is known that certain PCBs (coplanar PCBs such as 2,3,7,8Tetrachlorodibenzodioxin) act as powerful endocrine descriptors, affecting most of the endocrine system hormones, including thyroid hormones, steroid hormones, and corticosteroids (Miller-Pérez et al. 2009). Elevated plasma concentrations of PCBs have been correlated with the prevalence of type 2 diabetes mellitus (Silverstone et al. 2012). Similarly, PCBs are potent inhibitors of testosterone synthesis; significant PCBs concentrations in serum have been related to testosterone reduction in adolescents and adult males (Bell 2014). On the other hand, exposure to PCBs significantly affects the immune system, increasing infection incidence. People accidentally exposed to food contaminated with PCBs had respiratory tract and skin infections, a decrease in the concentration of immunoglobulins $\operatorname{Ig} \mathrm{A}$ and $\operatorname{IgM}$, and a reduction in the percentage of total $\mathrm{T}$ lymphocytes, active $\mathrm{T}$ lymphocytes, and T-helper (Th) lymphocytes (Miller-Pérez et al. 2009).

Similarly, perinatal exposure is associated with less. Thymic index in neonates (Faroon \& Ruiz 2016); this may be closely related to the immunological disorders 
observed due to the importance of this organ in the immune system's correct functioning (Tapha \& Farber 2019). Similarly, PCBs interfere with the function of various neurotransmitters such as dopamine, norepinephrine, and serotonin, affecting brain function (Mariussen \& Fonnum 2003). Other studies show an association between exposure to PCBs and motor and cognitive delay in infants (Berghuis \& Roze 2019). This would be closely related to the powerful interaction of PCBs with thyroid hormones (Prezioso et al. 2018); these displace thyroxine from its carrier protein, fetal transthyretin, allows thyroid hormone to enter the fetal brain, thus having the potential to alter normal brain development (Miller-Pérez et al. 2009).

On the other hand, exposure to PCBs has been closely associated with the prevalence of various types of cancers. For example, high PCB levels have been found in the blood of mothers of patients with testicular cancer (Faroon \& Ruiz 2016). PCBs have a powerful genotoxic, oxidizing, and enhancing effect on other compounds' carcinogenic effect. It has been observed that workers exposed to PCBs report an increase in different types of cancer, such as liver, gallbladder, biliary tract, gastrointestinal, skin, lymphomas non Hodgkin's, lung, pancreas, and brain (Miller-Pérez et al. 2009). The preceding shows that PCB monitoring and other POPs should be a topic of current interest due to the potential risk faced by the communities associated with the present study area and different ones in the country. The high prevalence of these pollutants in the various aquatic ecosystems.

The data presented in this work indicate that both the Barra de Navidad Lagoon and the Cuyutlán Lagoon show relatively low contamination levels and potential risk if we see them in a national and international context. However, exposure to POPs, even in low concentrations, presents a potential risk that can affect the health of local fish and people, especially those belonging to communities strongly dependent on these resources, such as the fishing communities of the riverine. On the other hand, the need for constant monitoring of the levels of pollutants present in the different environmental matrices of the country's aquatic ecosystems is evident, given the great information gap in this regard, particularly for the central Mexican Pacific.

\section{REFERENCES}

Abdel-Shafy, H.I. \& Mansour, M.S. 2016. A review on polycyclic aromatic hydrocarbons: source, environmental impact, effect on human health and remediation. Egyptian Journal of Petroleum, 25: 107-123.
Aguilar-Betancourt, C.M., González-Sansón, G., Kidd, K.A., Munkittrick, K.R., Curry, R.A., KosonoyAceves, D., et al. 2016. Fishes as indicators of untreated sewage contamination in a Mexican coastal lagoon. Marine Pollution Bulletin, 113: 100-109.

Astorga-Rodríguez, J.E., Martínez-Rodríguez, I.E., García-de la Parra, L.M., Betancourt-Lozano, M., Vanegas-Pérez, R.C., Ponce de León-Hill, C.A. \& Ruelas-Inzunza, J. 2018. Lead and cadmium levels in mussels and fishes from three coastal ecosystems of NW Mexico and its potential risk due to fish and seafood consumption. Toxicology and Environmental Health Sciences, 10: 203-211.

Baali, A. \& Yahyaoui, A. 2019. Polycyclic aromatic hydrocarbons (PAHs) and their influence to some aquatic species. In: Ondrasek, G. (Ed.). Organic pollutants, 2019. IntechOpen, London.

Batang, Z.B., Alikunhi, N., Gochfeld, M., Burger, J., AlJahdali, R., Al-Jahdali, H., et al. 2016. Congenerspecific levels and patterns of polychlorinated biphenyls in edible fish tissue from the central Red Sea coast of Saudi Arabia. Science of the Total Environment, 572: 915-925.

Behera, B.K., Das, A., Sarkar, D.J., Weerathunge, P., Parida, P.K., Das, B.K., et al. 2018. Polycyclic aromatic hydrocarbons (PAHs) in inland aquatic ecosystems: perils and remedies through biosensors and bioremediation. Environmental Pollution, 241: 212-233.

Bell, M.R. 2014. Endocrine-disrupting actions of PCBs on brain development and social and reproductive behaviors. Current Opinion in Pharmacology, 19: 134144.

Berghuis, S.A. \& Roze, E. 2019. Prenatal exposure to PCBs and neurological and sexual/pubertal development from birth to adolescence. Current Problems in Pediatric and Adolescent Health Care, 49: 133-159.

Brázová, T., Hanzelová, V. \& Šalamún, P. 2015. Ecological risk and distribution of polychlorinated biphenyls in fish. Emerging pollutants in the environment-current and further implications. IntechOpen, London.

Carvalho, F.P., Villeneuve, J.P., Cattini, C., Rendón, J. \& De Oliveira, J.M. 2009. Ecological risk assessment of PCBs and other organic contaminant residues in Laguna de Terminos, Mexico. Ecotoxicology, 18: 403416.

Collier, T.K., Anulacion, B.F., Arkoosh, M.R., Dietrich, J.P., Incardona, J.P., Johnson, L.J., et al. 2013. Effects on fish of polycyclic aromatic hydrocarbons (PAHS) and naphthenic acid exposures. Fish Physiology, 33: 195-255. 
Comisión Nacional de Pesca (CONAPESCA). 2017. Anuario estadístico de acuacultura y pesca. Comisión Nacional de Acuacultura y Pesca, Mazatlán. [https:// www.conapesca.gob.mx/work/sites/cona/dgppe/2017/ ANUARIO_ESTADISTICO_2017.pdf]. Reviewed: March 20, 2020.

Espinosa-Reyes, G., González-Mille, D.J., IlizaliturriHernández, C.A., Díaz-Barriga, F.M. \& MejíaSaavedra, J. 2012. Exposure assessment to persistent organic pollutants in wildlife: the case study of Coatzacoalcos, Veracruz, Mexico. Organic pollutants ten years after the Stockholm Convention. In: Puzyn, T. \& Mostrag-Szlichtyng, A. (Eds.). Environmental and analytical update. InTechOpen, London, pp. 114134.

Faroon, O. \& Ruiz, P. 2016. Polychlorinated biphenyls: new evidence from the last decade. Toxicology and Industrial Health, 32: 1825-1847.

FishBase. 2021. FishBase. [www.fishbase.org]. Reviewed: March 5, 2021.

Fitzgerald, E.F., Hwang, S.A., Bush, B., Cook, K. \& Worswick, P. 1998. Fish consumption and breast milk PCB concentrations among Mohawk women at Akwesasne. American Journal of Epidemiology, 148: 164-172.

García-Ruelas, C., Botello, A., Ponce-Vélez, G. \& DíazGonzález, G. 2004. Polycyclic aromatic hydrocarbons in coastal sediments from the subtropical Mexican Pacific. Marine Pollution Bulletin, 49: 514-519.

González-Jáuregui, M., Valdespino-Quevedo, C. \& Rendón von Osten, J. 2014. Residuos de contaminantes orgánicos persistentes (COP) en sedimentos del río Champotón y de la Reserva de la Biosfera de los Petenes, Campeche. In: Botello, A.V., Rendón von Osten, J., Benítez, J.A. \& Gold-Bouchot, G. (Eds.). Golfo de México. Contaminación e impacto ambiental: diagnóstico y tendencias. UAC, UNAMICMYL, CINVESTAV Unidad Mérida, Mérida, pp. 323-336.

González-Mille, D.J., Ilizaliturri-Hernández, C.A., Espinosa-Reyes, G., Costilla-Salazar, R., DíazBarriga, F., Ize-Lema, I. \& Mejía-Saavedra, J. 2010. Exposure to persistent organic pollutants (POPs) a DNA damage as an indicator of environmental stress in fish of different feeding habits of Coatzacoalcos, Veracruz, Mexico. Ecotoxicology, 19: 1238-1248.

Guo, W., Pan, B., Sakkiah, S., Yavas, G., Ge, W., Zou, W., et al. 2019. Persistent organic pollutants in food: contamination sources, health effects and detection methods. International Journal of Environmental Research and Public Health, 16: 4361.

Honda, M. \& Suzuki, N. 2020. Toxicities of polycyclic aromatic hydrocarbons for aquatic animals. International Journal of Environmental Research and Public Health, 17: 1363.
Instituto Nacional de Estadística y Geografía (INEGI). 2017a. Anuario estadístico y geográfico de Jalisco 2017. INEGI, Ciudad de México, pp. 854. [https:// transparencia.info.jalisco.gob.mx/sites/default/files/A nuario\%20Estad\%C3\%ADstico\%20y\%20Geogr\%C3 $\%$ A1fico\%20de\%20Jalisco\%202017.pdf]. Reviewed: March 20, 2020.

Instituto Nacional de Estadística y Geografía (INEGI). 2017b. Anuario estadístico y geográfico de Colima 2017. INEGI, Ciudad de México, [https://www. datatur.sectur.gob.mx/ITxEF_Docs/COL_ANUARIO _PDF.pdf]. Reviewed: March 20, 2020.

Islam, R., Kumar, S., Karmoker, J., Kamruzzaman, M., Rahman, M.A., Biswas, N., et al. 2018. Bioaccumulation and adverse effects of persistent organic pollutants (POPs) on ecosystems and human exposure: a review study on Bangladesh perspectives. Environmental Technology \& Innovation, 12: 115-131.

Jaward, F.M., Alegria, H.A., Galindo, J.G. \& Hoare. A. 2012. Levels of PAHs in the waters, sediments, and shrimps of Estero de Urias, an Estuary in Mexico, and their toxicological effects. The Scientific World Journal, 2012: 687034.

Jones, K.C. \& de Voogt, P. 1999. Persistent organic pollutants (POPs): state of the science. Environmental Pollution, 100: 209-221.

Karouna-Renier, N.K., Snyder, R.A., Lange, T., Gibson, S., Allison, J.G., Wagner, M.E. \& Rao, K.R. 2011. Largemouth bass (Micropterus salmoides) and striped mullet (Mugil cephalus) as vectors of contaminants to human consumers in northwest Florida. Marine Environmental Research, 72: 96-104.

Kljaković-Gašpić, Z., Romanić, S.H., Klinčić, D. \& Tičina, V. 2015. Chlorinated compounds in the muscle tissue of fish from the Croatian Adriatic: preliminary data on contamination and the associated health risks. Archives of Industrial Hygiene and Toxicology, 66: 299-308.

Mariussen, E. \& Fonnum, F. 2003. The effect of brominated flame retardants on neurotransmitter uptake into rat brain synaptosomes and vesicles. Neurochemistry International, 43: 533-542.

Miller-Pérez, C., Sánchez-Islas, E., Mucio-Ramírez, S., Mendoza-Sotelo, J. \& León-Olea, M. 2009. Los contaminantes ambientales bifenilos policlorinados (PCB) y sus efectos sobre el sistema nervioso y la salud. Salud Mental, 32: 335-346.

Mohamad, A., Azlan, A., Adon, M.Y., Khoo, H.E. \& Razman, M.R. 2015. Polychlorinated biphenyl and heavy metal exposures among fishermen in the Straits of Malacca: neurobehavioural performance. Asia Pacific Journal of Clinical Nutrition, 24: 515. 
Newman, M.C. \& Unger, M.A. 2002. Fundamentals of ecotoxicology. Lewis Publishers, Boca Raton.

Nozar, S.L.M., Ismail, W.R. \& Zakaria, M.P. 2013. Residual concentration of PAHs in seafood from Hormozgan province, Iran: human health risk assessment for urban population. International Journal of Environmental Science and Development, 4: 393.

Prezioso, G., Giannini, C. \& Chiarelli, F. 2018. Effect of thyroid hormones on neurons and neurodevelopment. Hormone Research in Paediatrics, 90: 73-81.

Ramírez-Ayala, E., Arguello-Pérez, M.A., Tintos-Gómez, A., Pérez-Rodríguez, R., Díaz-Gómez J.A., BorjaGómez, I., et al. 2020. Review of the biomonitoring of persistent, bioaccumulative, and toxic substances in aquatic ecosystems of Mexico: 2001-2016. Latin American Journal of Aquatic Research, 48(5): 705-738.

Ribeiro, C., Ribeiro, A.R. \& Tiritan, M.E. 2016. Occurrence of persistent organic pollutants in sediments and biota from Portugal versus European incidence: a critical overview. Journal of Environmental Science and Health - Part B: Pesticides, Food Contaminants, and Agricultural Wastes, 51: 143-153.

Romero-Romero, S., Herrero, L., Fernandez, M., Gómara, B. \& Acuña, J.L. 2017. Biomagnification of persistent organic pollutants in a deep-sea, temperate food web. Science of the Total Environment, 605: 589-597.

Rose, A., Ken, D., Alo, B. \& Kehinde, O. 2012. Bioaccumulation of polycyclic aromatic hydrocarbons in fish and invertebrates of Lagos Lagoon, Nigeria. Journal of Emerging Trends in Engineering and Applied Sciences, 3: 287-296.

Silverstone, A.E., Rosenbaum, P.F., Weinstock, R.S., Bartell, S.M., Foushee, H.R., Shelton, C. \& Pavuk, M. 2012. Polychlorinated biphenyl (PCB) exposure and diabetes: results from the Anniston Community Health Survey. Environmental Health Perspectives, 120: 727732.

Thapa, P. \& Farber, D.L. 2019. The role of the thymus in the immune response. Thoracic Surgery Clinics, 29: 123-131.

Tongo, I., Etor, E.E. \& Ezemonye, L.I.N. 2018. Human health risk assessment of PAHs in fish and shellfish from Amariaria Community, Bonny River, Nigeria. Journal of Applied Sciences and Environmental Management, 22: 731-736.

Received: October 6, 2020; Accepted: May 17, 2021
Torres, J. \& Quintanilla-Montoya, A.L. 2014. Alteraciones antrópicas: historia de la Laguna de Cuyutlán, Colima. Investigación Ambiental Ciencia y Política Pública, 6: 29-42.

Total Petroleum Hydrocarbon Criteria Working Group (TPHCWG). 1999. Development of toxicity criteria for petroleum hydrocarbon fractions in the Petroleum Hydrocarbon Criteria Working Group approach for risk-based management of total petroleum hydrocarbons in soil. Drug and Chemical Toxicology, 22: 275291.

United States Environmental Protection Agency (USEPA). 2015. SW-846 Compendium. [https://www.epa.gov/ hw-sw846/sw-846-compendium]. Reviewed: July 18, 2020.

United States Environmental Protection Agency (USEPA). 2000. Guidance for assessing chemical contaminant data for use in fish Volume 2: Risk assessment and fish consumption limits. USEPA, Washington, DC.

Vargas-González, H.H., Méndez-Rodríguez, L.C., García-Hernández, J., Mendoza-Salgado, R.A., Zenteno-Savín, T. \& Arreola-Lizárraga, J.A. 2016. Persistent organic pollutants (POPs) in populations of the clam Chione californiensis in coastal lagoons of the Gulf of California. Journal of Environmental Science and Health - Part B: Pesticides, Food Contaminants, and Agricultural Wastes, 51: 1-11.

Voorspoels, S., Covaci, A., Maervoet, J., De Meester, I. \& Schepens, P. 2004. Levels and profiles of PCBs and OCPs in marine benthic species from the Belgian North Sea and the Western Scheldt Estuary. Marine Pollution Bulletin, 49: 393-404.

Walpole, S.C., Prieto-Merino, D., Edwards, P., Cleland, J., Stevens, G. \& Roberts, I. 2012. The weight of nations: an estimation of adult human biomass. BMC Public Health, 12: 439.

Xu, F.L., Jorgensen, S.E., Shimizu, Y. \& Silow, E. 2013. Persistent organic pollutants in freshwater ecosystems. Scientific World Journal, 2013: 303815.

Zamora-Arellano, N.Y., Ruelas-Inzunza, J., GarcíaHernández, J., Ilizaliturri-Hernández, C.A. \& Betancourt-Lozano, M. 2017. Linking fish consumption patterns and health risk assessment of mercury exposure in a coastal community of NW Mexico. Human and Ecological Risk Assessment: An International Journal, 23: 1505-1521. 